\title{
КРЕАТИВНЫЕ ПРОЕКТЫ В СОЦИОКУЛЬТУРНОМ ПРОСТРАНСТВЕ ГОРОДА СМОЛЕНСКА
}

\section{CREATIVE PROJECTS IN THE SOCIAL AND CULTURAL SPACE OF THE CITY OF SMOLENSK}

\section{S. Asrieva}

Summary: In the article such notions as «historical city», "city space», "sociocultural space» are revealed. Special attention is paid to «mental image of the city", which significantly influences creative projects of sociocultural space of Smolensk. The content of the makerspace technology is revealed from the point of view of designing a collective creative workshop with involvement of different creative communities. Modern trends in the process of designing the social and cultural space of the city of Smolensk are described.

Keywords: historical city, city space, social and cultural space, mental image of the city, makerspace.

\author{
Асриева Снежана Вячеславовна \\ К.п.н., ОГБОУ ВО «СмоленскИй государственный \\ институт искусств» \\ sgii@mail.ru
}

Аннотация: В статье раскрываются такие понятия как «исторический город», «пространство города», «социокультурное пространство», Особое внимание уделяется «ментальному образу города», который существенно влияет на креативные проекты социокультурного пространства города Смоленска. Раскрывается и содержание технологии мейкерспейса, с точки зрения проектирования коллективной творческой мастерской с вовлечением разных творческих сообществ. Характеризуются современные тенденции в процессе проектирования социокультурного пространства города Смоленска.

Ключевые слова: исторический город, пространство города, социокультурное пространство, ментальный образ города, мейкерспейс.

высокой степенью дифференциации категории «норма»: привычки, обычаи, традиции, нравы; меньшей степенью отчуждённости горожан; интеграции различных форм и видов человеческой активности в контексте одной саморазвивающейся системы. [5]

Актуализация проблематики социокультурного пространства обусловлена неоднозначностью научного понимания и определения данного понятия.

В мировой и отечественной практике выделяют несколько ключевых подходов, интерпретирующих специфику пространства:

Семиотический подход (Н.П. Анциферов, Ю.М. Лотман, Д.Л. Спивак, А.С. Мухин, Е.В. Николаева); социологический подход (М. Вебер, Э. Дюркгейм, Дэвид Б., Кларк, Г. Зиммель, А. Лефевр, Л. Мамфорд); архитектурно-эстетический подход (Я. Гейл, Д. Фризби, Н.А. Масталерж, У. Митчелл и другие); антропологический подход (Ю. Хабермас); концепция «третьего места» (Р. Ольденбург).

В рамках данной статьи невозможно подробно рассмотреть все подходы, поэтому акцентируем внимание на социально-культурном подходе, представляющий наибольший интерес.

По мнению российских авторов Е.В. Зеленцова, С.А. Капкова, Н.В. Шарковской, Л.И. Шептухина он направлен на создание уникальной развивающей среды, обладающей вариативностью самоорганизованных форм не- 
формального общения людей на основе досуговых интересов и культурных потребностей, где инициаторами выступают сами члены данного сообщества различных возрастов. [1]

Пространство города - «территория», где объективно присутствуют источники социокультурного влияния: факторы (культурное наследие, традиции, культурный ландшаф) и субъекты (сферы жизнедеятельности горожан), где вступают в силу определённые закономерности и принципы, способствующие - созданию креативной среды.

Наиболее популярное определение социокультурного пространства города, принадлежит И.В. Тулигановой, согласно которой - это «система информационнокоммуникативных оснований социальной деятельности, воплощенных в разнообразных знаково-символических продуктах социокультурной практики, локализованных в определенных территориальных границах. [6]

В современных исследованиях все чаще прослеживается сравнение города с брендом - в русской языковой культуре оно аналогично понятию «торговая марка».

Сегодня существенным преимуществом региона является уникальный бренд «Смоленск - один из древнейших городов России». Это ментальный образ территории, который сложился у смолян или людей, посещающих, или кто о нем когда-либо слышал.

Сегодня он используется как концепт, маркирующий особенности социокультурного пространства города.

По мнению А.Я. Гуревича «ментальность» - есть некий «психологический инструментарий» и «специфическая структура сознания». [5]

В общественном сознании россиян генерализированы и другие образы, позиционирующие Смоленск как: «Город - Крепость», «Город-щит», «Город - воин», «Смоленщина льняная»; представление о городе, как западном форпосте православия, земле патриарха, родине святых Бориса и Глеба, подкрепленные очень значимыми материальными составляющими как икона Одигитрии, Успенский Собор. [3]

В русскую историю Смоленск вошел под названием «Город-ключ», так как он много раз был своеобразным щитом, ключом к сердцу России - городу Москве. Смоленская область - наследница исторических традиций древней Смоленской земли. [2]

Это означает, что в восприятии, представлении, отношений, территориального поведения жителей Смоленска важную роль играет «Древнерусская тематика».

Историческая и культурная тематика Смоленска бук- вально разобрана на «цитаты»: текстовые и визуальные изображения (объявления, реклама, календари), название предприятий, банков «Смоленский», ресторан «Смоленская крепость», фестиваль исторической реконструкции и славянской культуры «Гнёздово», кинофестиваль «Феникс»; «стихийные» упоминания древней истории в пространстве города: граффити на стене «Варяги за Русь!». Как исключительный случай - использование псевдославянского шрифта кафе «Самоваръ. [2]

Максимальная концентрация этих объектов сосредоточена в историческом центре города, на набережной Днепра, а также местах ярмарок и проведения досуга вдоль главных улиц, вокруг площадей, в парках.

В исторической тематике города прослеживаются и другие компоненты: польский, белорусский, дореволюционый, военный, советский.

Такое обильное наследие рождает в людях чувство гордости за место своего обитания, чувство сопричастности. При этом спецификой креативного проектирования в социокультурном пространстве является создание креативной среды, формируемой в границах этого пространства, являющейся средоточием импульсов и стимулов для развития творчества, инициативы горожан. Это своеобразный перекрёсток солидарных действий, отношений, настроения горожан, формирующие и воспроизводящие городские идентичности.

Особый интерес представляет проектирование мейкерспейсов.

Мейкерспейс - это публичное пространство, интегрирующее традиционные ремёсла и новые технологии; рассчитанное на коллаборацию специалистов и любителей и их труд с материальными объектами (индивидуальное производство).

По сути, это коллективная творческая мастерская сообщество творческих людей, объединённых общими интересами делами, чтобы творить, генерировать новые идеи, создавать и продвигать свой проект. Это место, куда может прийти любой горожанин любого возраста и профессии, гость города, воспользоваться оборудованием и материалом, и воплотить свою идею.

Появление мейкерства в России связанно с движением «Сделай сам», которое зародилось в 1940 -е годы в Америке. В основе движения лежит принцип: «Люди должны быть творцами, а не потребителями». [4]

Примером мейкерспейса является творческая мастерская «Смоленская Изба, объединяющая традиции гончарного дела и новые технологии. Основная цель:

- приобщение к народной культуре, изучение и передача навыков традиционного искусства;

- ориентация на производство по индивидуальным 
запросам;

- приобщение к новым технологиям;

- экологическое сознание (влияние материала на окружающую среду);

- развитие социокультурных связей, основанных на свободных коммуникациях;

- самореализация, развитие творческого потенциала.

Здесь каждый может научиться керамическому делу, принять непосредственное участие в работе на гончарном круге, лепке из глины или росписи изделий. Это место, где рождаются новые инициативы для города, горожан и себя.

Кроме того, можно разработать собственную коллекцию сувениров, а также изделий по индивидуальному заказу, необычных корпоративных сувениров или продать в лавке уникальных товаров «Своя полка» для горожан и гостей города.

Именитые смоленские мастера, являются наставниками. Это молодые, креативные, творческие люди, готовые делиться своими знаниями, демонстрировать свои умения, обучать и помогать создавать настоящие произведения искусства. Все занятия проходят с элементами интерактива. [2]

Интерактивное взаимодействие всех субъектов, даёт возможность включиться в продуктивный диалог, где создаётся определённая творческо - развивающая среда, где ключевыми словами является: «действую, думаю, творю, принимаю решение». Отсюда, основу интерактивного взаимодействия составляет «культурное событие», интерактивные лекции, концерты. В эту структуру входят и мастер-классы приглашённых специалистов, презентации уникальных творческих работ.

В проектировании креативных проектов в современном социокультурном пространстве города Смоленска можно выделить следующие тенденции:
1. Тематизация городских локаций в зависимости от сосредоточения исторических ансамблей: примером может служить международный фестиваль исторической реконструкции и славянской культуры «Гнёздово», которому семь лет. Творческая идея фестиваля - историческая реконструкция дружинной культуры и условий жизни населения одного из крупнейших раннегородских центров Древней Руси - Гнёздово. Программа включает: реконструированные военно-полевые лагеря славян и варягов; показательные выступления воинов; индивидуальные турниры, бои пятёрок, массовое сражение; конкурс исторического костюма; ярмарка средневековых товаров; ремесленные мастер-классы и эксперименты; лучный и суличный тиры; аутентичная кухня; выступление фолк-групп. [2]

2. Проектирование креативных проектов в торговоразвлекательных центрах. Креативность, досуг становятся его новым элементом, а материальные продукты и сервис уходят на второй план. Современные торговые центры присваивают черты классических социально-культурных институтов, так как в нём появляются зоны для экспозиций, проведения мастер-классов, интерактивных лекций, конференций; выставочные центры, творческие студии, зоны коворкинга, центры современного искусства, всевозможные учебные центры, зоны для проведения концертов, праздников города, зрелищных шоу программ, квест игр итд.

Каждая из перечисленных тенденций, разумеется, требует своего самостоятельного рассмотрения. Это, несомненно, способствует создание условий для личностных креативных практик горожан, и предоставляет возможности для социальной практики специалистам социально-культурной сферы, через которых преображается социокультурное пространство города.

\section{ЛИТЕРАТУРА}

1. Акунина, Ю.В. Проектирование креативных общественных пространств: социокультурный подход / Ю.В. Акунина, 0.В. Ванина // Вестник Московского государственного университета культуры и искусств. 2019. - № 3(89). - С. 169-173.

2. Визит-Смоленск: [электронный журнал]. - URL: http://www.visitsmolensk.ru/chem-zanyatsya/tvorchestvo/. - Режим доступа: для авторизир. пользователей. - Текст: электронный

3. Замятин, Д.Н. Моделирование образов историко-культурной территории: методологические и теоретические подходы / Д.Н. Замятин, Н.Ю. Замятина, И.И. Митин. - М.: Институт наследия, 2010. - 760 с.

4. Иванова, Е.В. Университетский мейкерспейс: территория творчества и взаимодействия // Молодёжь и общество. - 2015. - № 4. - С. 56-61.

5. Порозов, Р.Ю. Культурно-образовательное пространство города: монография / Р.Ю. Порозов ; Урал. гос. пед. ун-т. - Екатеринбург, 2016. - 174 с.

6. Тулиганова, И.В. Социокультурное пространство современного города: автореферат диссертации / И.В. Тулиганова. - Саратов, 2009. - 18 с.

(c) Асриева Снежана Вячеславовна (sgii@mail.ru). 